Article

\title{
Optimization of Pollen Germination in Tectona grandis (Teak) for Breeding Programs
}

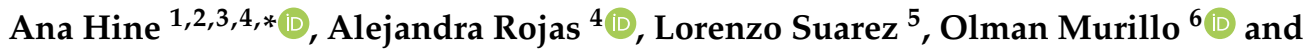 \\ Mario Espinoza ${ }^{7}$ (D) \\ 1 Doctorado en Ciencias Naturales para el Desarrollo (DOCINADE), Universidad Estatal a Distancia, \\ CP 11502 San José, Costa Rica \\ 2 Doctorado en Ciencias Naturales para el Desarrollo (DOCINADE), Instituto Tecnológico de Costa Rica, \\ CP 30101 Cartago, Costa Rica \\ 3 Doctorado en Ciencias Naturales para el Desarrollo (DOCINADE), Universidad Nacional, \\ CP 86-3000 Heredia, Costa Rica \\ 4 Instituto de Investigación y Servicios Forestales, Universidad Nacional, CP 86-3000 Heredia, Costa Rica; \\ alejandra.rojas.vargas@una.cr \\ 5 Instituto Nacional de Ciencias Agrícolas, CP 32700 Mayabeque, Cuba; lguerra@inca.edu.cu \\ 6 Instituto Tecnológico de Costa Rica, Escuela de Ingeniería Forestal, CP 30101 Cartago, Costa Rica; \\ omurillo@tec.ac.cr \\ 7 Novelteak, CP 63-5000 Liberia, Costa Rica; mario.espinoza@novelteak.com \\ * Correspondence: ana.hine.gomez@una.cr
}

Received: 20 August 2019; Accepted: 30 September 2019; Published: 16 October 2019

\begin{abstract}
Teak has become one of the most widely planted species in tropical regions of the world, given its high price for its timber in international markets. This has motivated the development of tree improvement programs in the Latin American region and in the tropical world in general. The latest advances have achieved clonal forestry at an operational scale. Recently, important efforts are being made to advance towards the next breeding generation, since knowledge about floral biology and pollen management have become important issues. A breeding program is being developed through the Tree Improvement Cooperative GENFORES-a vinculation model between the academy and forestry companies that was initiated in Costa Rica and now involves six Latin American countries. In order to advance into the next breeding generations, building capacities in topics such as pollen banks requires pollen quality, thus enabling the exchange of pollen among cooperative members. Pollen fertility studies are of considerable value in breeding programs, in order to determine pollen viability and germination in collections of genotypes, before going into mating operational activities. In this study, we optimized pollen quality analysis protocols in terms of the viability and germination of fresh teak pollen. Results of this research show that $90 \%$ viability and $28 \%$ germination can be achieved in fresh pollen grains, both inside and outside the anther, previously dehydrated in silica gel for 2 to $4 \mathrm{~h}$ (40\% and 33\% humidity, respectively). Brewbacker and Kwack (BK) medium at 10\% of its salts $+10 \%$ sucrose and at a $\mathrm{pH}$ of 7 must be used as the germination medium. It is possible to evaluate teak pollen quality using the parameters defined in this study, which will in turn allow pollen management and purification, providing an opportunity for carrying out controlled crosses at an operational scale as part of teak breeding programs.
\end{abstract}

Keywords: forest plantations; tree improvement; teak; pollen management

\section{Introduction}

Teak (Tectona grandis L. f.) is a tree native to Southeast Asia and can reach 45 to $50 \mathrm{~m}$ in height and 2 to $2.5 \mathrm{~m}$ in diameter at breast height (DBH) in its place of origin. Due to its strength, 
resistance, workability and aesthetic qualities, teak is considered to be one of the most valuable woods for furniture, shipbuilding, docks or piers, freshwater bridges and floodgates, railway ties, parquet floors, poles for electric transmission lines, and fences, as well as for musical instruments and toys $[1,2]$.

The great economic importance that teak currently has due to its wood value has stimulated the development of breeding programs. In Latin America, the first program was probably implemented in Trinidad and Tobago, with the participation of British scientists [3,4]. The increased growth and timber yield of teak became the essential goals of breeding programs around the world [3].

Worldwide, there is currently great interest in achieving progress towards the second generation of breeding teak, which requires the development of controlled pollination techniques and pollen management capacity in general [3,5]. New challenges have appeared in recent years. Many of them can be approached through breeding efforts, such as diseases resistance, drought resistance, and heartwood color control, among other topics related to productivity, adaptability and markets acceptance [3,6-8]. Therefore, there is an urgent need to make progress in the genetic improvement of Teak.

Asian researchers have been able to pollinate teak under controlled conditions using fresh pollen; however, their reports have only been presented at a scientific level, and their studies are neither part of structured tree improvement programs, nor any advanced breeding generation at an operational scale. Thus, the available information on teak pollen will be instructional for operational breeding purposes [9-13].

Palupi and Owens [11] carried out studies on pollination, fertilization and embryo production. At the same time, Tangmitcharoen and Owens $[9,10]$ also performed two projects; one related to the study of the floral biology, pollination, pistil receptivity, and growth of the pollen tube of teak pollen, and another dealing more specifically with pollen viability, pollen tube growth and controlled pollination, as these factors relate to the low production of teak fruits. Palupi et al. [14] studied the importance of fruiting, fruit abortion, and the success of both open and cross-pollination in the production of teak fruits.

However, despite these previous studies, no efficient protocols have been developed to determine the quality of teak pollen. According to Rejón et al. [15], pollen quality is a fundamental parameter for studies of the biology of pollination, specifically in terms of the selection of pollinating varieties, pollen-pistil recognition, germination, pollen tube growth and fertilization. Furthermore, germination in vitro has been used as a method to determine the viability of pollen. This method, however, requires previous studies to standardize the culture medium, so as to allow optimal germination [16]. The main objective of the present study is to optimize a teak pollen germination procedure, in order to support advanced generations of genetic improvement.

\section{Materials and Methods}

This research was carried out in the Forest Biotechnology Laboratory (FBL) of the Forest Research and Services Institute of the National University (UNA), as part of the teak genetic improvement program developed by the Tree Improvement Cooperative GENFORES. The fieldwork was carried out at the facilities of Novelteak, a company member of the cooperative, in La Cruz, Guanacaste, Northern Pacific of Costa Rica.

Pollen was collected from clonal trials established in La Cruz, between 05:00 and 07:00 as suggested by other authors $[9,17,18]$, in order to obtain flowers that were not completely open and facilitate the capture of fresh pollen. The fresh panicles were kept in a room at $25^{\circ} \mathrm{C}$, where unopened flowers were utilized. They were placed in sealed bags for one hour to induce opening. Once the flowers were open, mechanical extraction of the anthers was carried out with the aid of scissors. 


\subsection{Effect of Dehydration on the Viability and Germination of Pollen Inside and Outside the Anther}

Pollen was analyzed inside and outside the anther. To evaluate the effect of dehydration $(0,2$, $3,4 \mathrm{~h}$ in silica gel) on teak, the methods of morphological staining and in vitro germination were used [19]. In the first instance, dehydration was used to determine the moisture content in which the dehiscence of the anthers was induced and, therefore, the availability of pollen grains. To determine the percentage of pollen viability, $1 \%$ acetocarmine was used as colorant. Constricted and unstained pollen grains were considered to be unviable, while those that were round red-colored were considered to be viable. The staining of pollen grains with acetocarmine is commonly used to evaluate pollen fertility. As the fertile pollen grains absorb the dye, they become deeply and uniformly colored. On the other hand, sterile or dead pollen grains are withered, with little cellular content or empty spaces [16].

The in vitro germination method was used to determine the percentage of germination, using Brewbacker and Kwack (BK) medium [20] at 10\% of its salts (g/100 mL) $+10 \%$ sucrose $(\mathrm{g} / 100 \mathrm{~mL})$ in an aqueous solution with at a $\mathrm{pH}$ of 7 . Only those grains with a pollen tube with a length greater than or equal to the diameter of the pollen grain were considered to have germinated [19]. A pollen tube is defined as a projection of the pollen grain, which is at least half the width of a pollen grain [21]. The percentage of viability and germination was determined taking into account the number of viable and germinated grains with respect to the total number of grains found in each microscopic field. The effects of dehydration on viability and in vitro germination were analyzed by a randomized complete bloc design, with 4 treatments (dehydration hours). Each treatment had 3 repetitions, with 5 readings per repetition. Pollen counts were carried out using a Nikon ALPHAPHOT-2 YS2 microscope with a $10 \times$ lens on 100 to 200 pollen grains per optical field (10×).

\subsection{Effect of $\mathrm{pH}$ on Viability and in vitro Germination of Pollen}

Anthers were dehydrated in containers with silica gel (50 g per container) for 0, 2, 4, and $6 \mathrm{~h}$. Pollen from each dehydration period was used to visualize the pollen viability and germination. For viability, morphological staining with $1 \%$ acetocarmine was used, while for germination, BK medium [20] was used as a control media at $10 \%$ of its salts $+10 \%$ sucrose with $\mathrm{pH}$ ranges of $6.0 ; 6.3 ; 6.5 ; 6.8$ and 7.0 ; respectively. The effects of $\mathrm{pH}$ on in vitro germination were analyzed by a randomized complete bloc design, with 5 treatments $(\mathrm{pH})$. Each treatment had 3 repetitions, with 5 readings per repetition.

\subsection{Determination of the Dehydration Curve and Survival of Pollen}

The anthers were dehydrated in containers with silica gel (50 g per container) for $0,2,4$, and $6 \mathrm{~h}$ to determine their moisture content. Specifically, $0.1 \mathrm{~g}$ of anther was used per dehydration period. The fresh weight (FW) was calculated at the beginning of the process, and the dry weight (DW) was determined at the end of the process. The percentage of moisture content was calculated according to the formula: $[((\mathrm{FW}-\mathrm{DW}) / \mathrm{FW}) \times 100][18,22]$. Once the anthers were dehydrated, they were deposited in $2.5 \mathrm{~mL}$ vials. The pollen was separated from the anther by shaking the vial with a Vortex at a low intensity for $3 \mathrm{~min}$. Once the pollen was isolated, the percentage of viability and germination was determined using morphological staining with $1 \%$ acetocarmine and BK medium [20] at $10 \%$ of its salts $(\mathrm{g} / 100 \mathrm{~mL})+10 \%$ sucrose $(\mathrm{g} / 100 \mathrm{~mL})$ in an aqueous solution at a $\mathrm{pH}$ of 7 [19]. The dehydration curve and pollen survival were analyzed by a randomized complete bloc design, with 4 treatments (dehydration hours), each treatment had 3 repetitions, with 5 readings per repetition.

\subsection{Effect of the Culture Medium on the Viability and Germination of Pollen}

To measure the effect of the type of germination medium on the percentage of viability and germination of teak pollen, anthers were dehydrated for $2 \mathrm{~h}$ in silica gel. Afterwards, pollen was isolated from the anther in a similar procedure as above and was finally germinated in the media described in Table 1 . The effect of the type of germination medium was analyzed by a randomized 
complete bloc design, with 3 treatments (medium). Each treatment had 3 repetitions, with 5 readings per repetition.

Table 1. Culture media used for the in vitro germination of pollen previously dehydrated in silica gel for $2 \mathrm{~h}$.

\begin{tabular}{cc}
\hline Medium & Formulation \\
\hline Medium 1 & $10 \%$ sucrose $(\mathrm{g} / 100 \mathrm{~mL})$ in aqueous solution at a $\mathrm{pH}$ of 7 \\
\hline Medium 2 & $\begin{array}{c}14 \% \text { sucrose }(\mathrm{g} / 100 \mathrm{~mL}) \text { in aqueous solution at a } \mathrm{pH} \text { of } 7 \\
\text { Medium 3 }\end{array}$ \\
$\begin{array}{c}\text { BK medium at } 10 \% \text { of its salts }+10 \% \text { sucrose }(\mathrm{g} / 100 \mathrm{~mL}) \\
\text { in aqueous solution at a } \mathrm{pH} \text { of } 7\end{array}$ \\
\hline
\end{tabular}

\subsection{Statistic Analysis}

To carry out the statistical analysis, the values in the percentage of viability and in vitro pollen germination were previously transformed. The transformation of arcsen $\sqrt{\% \text { germinación/viabilidad }}$ was used. The transformed and untransformed data were subjected to an analysis of variance. They were analyzed by a randomized complete bloc design. In all the trials, each treatment had 3 repetitions, with 5 readings per repetition. Differences between treatments were evaluated using the Tukey multiple comparison test at 95\% confidence using the InfoStad and Statistica program [23,24].

\section{Results}

\subsection{Effect of Dehydration on the Viability and Germination of Pollen Analyzed Inside and Outside the Anther}

When we evaluated the effect of dehydration on the viability of fresh teak pollen, a statistically significant difference was found between the treatments (dehydration periods) analyzed both inside $(p \leq 0.001)$ and outside the anther $(p \leq 0.006)$ (Table 2$)$. The highest viability percentages $(90 \%$ and $88 \%$, respectively) were obtained at $2 \mathrm{~h}$ of dehydration for both treatments. It is important to note that the viability percentages remained above $70 \%$ for all periods of dehydration. On the other hand, when we evaluated the effect of dehydration on in vitro germination of fresh teak pollen, both inside and outside the anther, a statistically significant difference was found between dehydration periods $(0,2$, 4 , and $6 \mathrm{~h}$ ) - both for the pollen analyzed inside and for the pollen that was extracted from the anther $(p \leq 0.001)$. With regards to the germination of dehydrated pollen grains inside the anther, a progressive reduction was observed from $43 \%$ at the moment of anthesis $(0 \mathrm{~h})$ to $10 \%$ at $6 \mathrm{~h}$. A similar pattern was observed when the effect of dehydration on the percentage of the germination of pollen grains extracted from the anther was evaluated, showing a reduction in the percentage of germination from $53 \%$ at $0 \mathrm{~h}$ to $22 \%$ after $6 \mathrm{~h}$ of dehydration; however, it was not possible to distinguish the effects of 2 and $4 \mathrm{~h}$ of dehydration on the percentage of germination, which was $28 \%$ on average.

Table 2. Effect of dehydration in silica gel on the percentage of viability (A) and germination (B) of teak pollen germinated in BK medium at $10 \%$ of its salts $+10 \%$ sucrose and stained with $1 \%$ acetocarmine, analyzed inside and outside the anther.

\begin{tabular}{ccccc}
\hline \multirow{2}{*}{ Dehydration (h) } & \multicolumn{2}{c}{ Viability (\%) } & \multicolumn{2}{c}{ Germination (\%) } \\
\cline { 2 - 5 } & Inside & Outside & Inside & Outside \\
\hline 0 & $75.47 \pm 10.29 \mathrm{c}$ & $86.45 \pm 1.38 \mathrm{a}$ & $43.22 \pm 2.18 \mathrm{a}$ & $52.72 \pm 2.01 \mathrm{a}$ \\
2 & $90.00 \pm 0.00 \mathrm{a}$ & $87.96 \pm 0.85 \mathrm{a}$ & $20.77 \pm 3.71 \mathrm{~b}$ & $23.28 \pm 1.74 \mathrm{bc}$ \\
4 & $89.00 \pm 3.47 \mathrm{a}$ & $84.83 \pm 2.07 \mathrm{~b}$ & $4.68 \pm 1.3 \mathrm{c}$ & $32.73 \pm 4.33 \mathrm{ab}$ \\
6 & $83.20 \pm 13.87 \mathrm{~b}$ & $70.46 \pm 7.24 \mathrm{c}$ & $10.07 \pm 1.95 \mathrm{c}$ & $21.69 \pm 2.57 \mathrm{c}$ \\
\hline
\end{tabular}

Different letters indicate statistically significant differences between treatments (Tukey, $p \leq 0.05$ ). 


\subsection{Effect of $\mathrm{pH}$ on the Viability and In Vitro Germination of Pollen}

On the other hand, an evaluation of the effect of $\mathrm{pH}$ on the viability and germination of dehydrated pollen (Table 3) showed that the treatment with $2 \mathrm{~h}$ of dehydration and $\mathrm{pH}$ between 6.3 and 7 produced the highest percentage of viability $(90 \%)$. With regards to the percentage of germination, it was found that treatments with $2 \mathrm{~h}$ of dehydration and a $\mathrm{pH} 7.0$ produced the highest percentages of germination compared to other periods of dehydration.

Table 3. Effect of $\mathrm{pH}$ on the viability and germination of pollen, dehydrated for $0 \mathrm{~h} \mathrm{(a),} 2 \mathrm{~h}(\mathrm{~b})$, and $4 \mathrm{~h}(\mathrm{c})$.

\begin{tabular}{cccc}
\hline Time (h) & $\mathbf{p H}$ & Variability (\%) & Germination (\%) \\
\hline & 6 & $74.72 \pm 1.91 \mathrm{abcd}$ & $19.61 \pm 2.59 \mathrm{abc}$ \\
& 6.3 & $72.25 \pm 6.01 \mathrm{bcd}$ & $16.35 \pm 2.36 \mathrm{bc}$ \\
0 & 6.5 & $77.95 \pm 4.92 \mathrm{abcd}$ & $29.44 \pm 3.87 \mathrm{abc}$ \\
& 6.8 & $68.33 \pm 1.62 \mathrm{~cd}$ & $19.48 \pm 5.05 \mathrm{abc}$ \\
& 7 & $65.54 \pm 6.30 \mathrm{~d}$ & $29.96 \pm 2.66 \mathrm{abc}$ \\
\hline & 6 & $73.60 \pm 1.73 \mathrm{bcd}$ & $32.23 \pm 2.97 \mathrm{abc}$ \\
& 6.3 & $83.58 \pm 2.76 \mathrm{abc}$ & $36.28 \pm 10.55 \mathrm{abc}$ \\
& 6.5 & $86.11 \pm 3.89 \mathrm{ab}$ & $41.15 \pm 7.69 \mathrm{ab}$ \\
& 6.8 & $90.00 \pm 0.00 \mathrm{a}$ & $29.00 \pm 8.50 \mathrm{abc}$ \\
& 7 & $83.88 \pm 3.78 \mathrm{abc}$ & $45.78 \pm 9.99 \mathrm{a}$ \\
\hline & 6 & $74.44 \pm 2.12 \mathrm{abcd}$ & $13.62 \pm 1.56 \mathrm{c}$ \\
& 6.3 & $77.67 \pm 0.83 \mathrm{abcd}$ & $42.36 \pm 5.29 \mathrm{ab}$ \\
& 6.5 & $81.42 \pm 0.5 \mathrm{abcd}$ & $12.81 \pm 1.9 \mathrm{c}$ \\
& 6.8 & $79.74 \pm 2.58 \mathrm{abcd}$ & $15.57 \pm 2.77 \mathrm{bc}$ \\
& 7 & $78.14 \pm 0.77 \mathrm{abcd}$ & $12.81 \pm 1.12 \mathrm{c}$ \\
\hline
\end{tabular}

Different letters indicate statistically significant differences between treatments (Tukey, $p \leq 0.05$ ).

\subsection{Determination of the Dehydration Curve and Survival of Pollen}

The evaluation of the effect of dehydration on the percentage of viability indicates that the percentage of viability remained constant $(86 \%)$ over time and that there was no statistically significant difference during the first $4 \mathrm{~h}(p \leq 0.006)$ (Figure 1a). With regards to the percentage of germination, a significant statistical difference was found between different hours of dehydration $(p \leq 0.001)$ - on average, $28 \%$ of germinated pollen grains were obtained between 2 and $4 \mathrm{~h}$ of dehydration (Figure $1 \mathrm{~b}$ ). Based on the above, it was determined that the minimum percentage of moisture content (MC) that pollen grains can tolerate before dehydration is between $40 \%$ and $33 \%$, which occurs at 2 and $4 \mathrm{~h}$ of dehydration, respectively (Figure 1c). In addition, it was found that as the dehydration time increases, pollen falls off the anther more easily; therefore, less scattered pollen in the germination medium is observed at $0 \mathrm{~h}$ of dehydration, and more dispersed pollen is observed after $2 \mathrm{~h}$ of dehydration. 

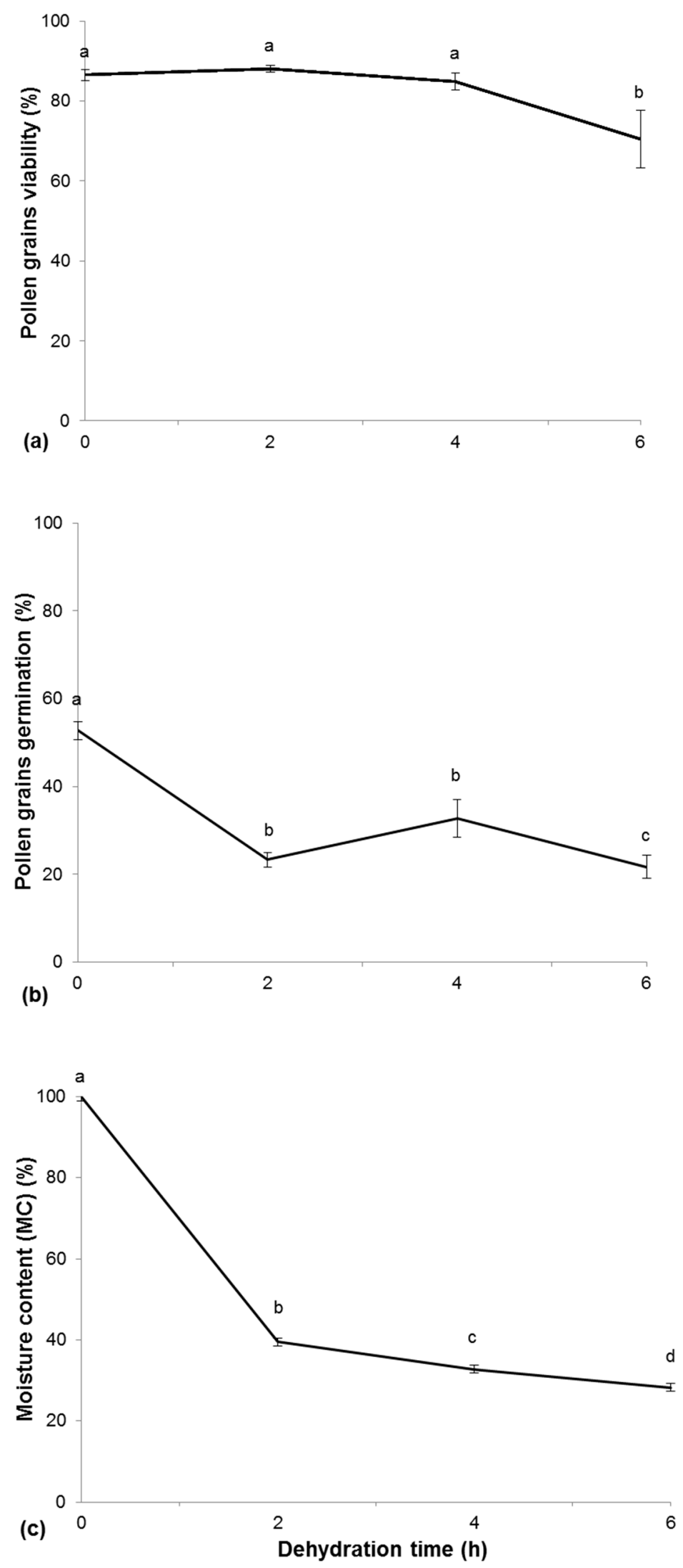

Figure 1. (a) Viability percentage of pollen grains; (b) The percentage of germination of pollen; (c) Moisture content (MC), after dehydration in silica gel for 0, 2, 4 and $6 \mathrm{~h}$. The lowercase letters used in the graph to show significant statistical differences. 


\subsection{Effect of the Culture Media on the Viability and Germination of Pollen}

The evaluation of the effect of the culture medium on the viability of fresh teak pollen isolated from the anther, and stained with $1 \%$ acetocarmine, found no statistically significant difference between treatments (Table 4), with a percentage of viability of $90 \%$ in each of the three culture media used. With regards to the percentage of germination, a statistically significant difference between treatments was found $(p \leq 0.001)$ (Table 4$)$, with the highest percentage of germination $(28.99 \%)$ in medium 3-BK medium at $10 \%$ of its salts $+10 \%$ sucrose.

Table 4. Effect of different culture media on the percentage of viability and germination of fresh teak grains, previously dehydrated in silica gel for $2 \mathrm{~h}$.

\begin{tabular}{ccc}
\hline Medium & Viability (\%) & Germination (\%) \\
\hline Medium 1 & 90 & $5.14 \pm 1.33 \mathrm{~b}$ \\
\hline Medium 2 & 90 & $5.35 \pm 1.26 \mathrm{~b}$ \\
\hline Medium 3 & 90 & $28.99 \pm 1.53 \mathrm{a}$ \\
\hline
\end{tabular}

\section{Discussion}

In order to develop a methodology to evaluate pollen quality, it is necessary to establish different stages that make it possible to estimate quality in terms of viability and germination through the optimization of in vitro pollen germination [15]. During the dehydration trials, it was determined that the moisture content at which pollen grains tolerate dehydration is between $40 \%$ and $33 \%$, which are reached at 2 and $4 \mathrm{~h}$ of dehydration in silica gel. Dehydration is closely related to the pollen viability of pollen grains. Furthermore, immediately after harvesting, different authors have recommended determining a percentage of moisture content close to $30 \%$, at which the pollen grain is tolerant to dehydration and can be managed and stored $[17,18]$. On the other hand, it must be recognized that field conditions and relative humidity at the time of harvest affect pollen moisture content, making it necessary to develop a methodology for the determination of the moisture content of the pollen grains at the moment of harvesting, and hours after harvesting. However, in tropical species such as teak, fresh, ripe, and dry pollen grains extracted directly from the anthers are in physiologically ideal conditions to be collected and stored [17].

With respect to the evaluation of the viability of the pollen grains, both inside and outside the anther and after dehydration with silica gel, it was found that the location from which the pollen is collected does not affect the viability percentage. Results showed $90 \%$ viability for both types of samples after 2 and $4 \mathrm{~h}$ of dehydration, which is in agreement with Tangmitcharoen and Owens [10], who found $92.2 \%$ viability in pollen collected $4 \mathrm{~h}$ after anthesis.

On the other hand, Tangmitcharoen and Owens [10] only reported having observed the germination of pollen grains one hour after they were placed in BK medium [20] at $10 \%$ of its salts $+10 \%$ sucrose. The present study determined that this same medium improved the germination of pollen extracted from the anther after being dehydrated for 2 and $4 \mathrm{~h}$, finding an average of $28 \%$ germination under these conditions. This result confirms that pollen dehydrated and extracted from the anther, can not only germinate in vitro, but also allows genetic improvement programs to start from an initial percentage of germination, which is critically important in the design of future hybridization trials. The in vitro germination test is based on the ability of pollen grains to germinate in an optimal nutrient medium. This is a quick and simple routine test, which has been used to measure pollen viability and germination [16]. 
According to Johnson and Kost [21], it is possible to induce the growth of pollen tubes in most species by cultivating the pollen grains in simple media containing only carbohydrates, borate and calcium. In addition, these same authors mention that under in vitro conditions, pollen tubes generally elongate at lower rates than those that occur under in situ conditions. On the other hand, the results obtained in the germination media trials suggest that adding only sucrose to the medium was not sufficient to induce the germination of teak pollen. These results indicate that macronutrients such as calcium, potassium and magnesium, as well as the micronutrient boron, are essential in inducing the germination of the pollen tube. The $\mathrm{BK}$ medium used in this investigation includes the following nutrients in solution: $\mathrm{Ca}\left(\mathrm{NO}_{3}\right)_{2}, \mathrm{KH}_{2} \mathrm{PO}_{4}, \mathrm{MgSO}_{4}, \mathrm{KNO}_{3}$. These have been widely used in the formulation of culture media for pollen germination in many species. This is due to the fact that cell walls are formed during the process of the elongation of the pollen tube, a process in which $\mathrm{Ca}^{2+}$ plays a fundamental role as a constituent of the middle layer of the cell walls. In addition, $\mathrm{Ca}^{2+}$ is required as a cofactor by some enzymes involved in ATP and phospholipid hydrolysis, and acts as a second messenger in metabolic regulation. A requirement for $\mathrm{K}^{+}$and $\mathrm{Mg}^{2+}$ ions for the elongation of pollen tubes has also been observed, since they work as regulators of the association of $\mathrm{Ca}^{2+}$ with the cell wall $[20,25]$.

In addition, the pollen physiology is activated during rehydration, observing increased calcium levels in the cytosol. This calcium triggers the rearrangement of the pollen cytoskeleton and produces the physiological and structural polarization of the pollen grain. These authors mention that this polarized growth may be due to an ion gradient, specifically referring to the $\mathrm{Ca}^{2+}$ ion and to a $\mathrm{pH}$ gradient ranging between 6.8 and 7.5 in the apical and subapical regions of the pollen tube. The electrical and chemical changes due to the concentration of $\mathrm{Ca}^{2+}$ and $\mathrm{pH}$ play an important role in cell signaling, in cytoskeletal dynamics, in membrane trafficking and in exocytosis $[25,26]$. This confirms the data obtained in the trial when measuring the effect of $\mathrm{pH}$ on the germination of teak pollen-in which, it was observed that the best percentage of germination was found in a $\mathrm{pH}$ range of 6.5 to 7 in pollen extracted from the anther after 2 and $4 \mathrm{~h}$ of dehydration.

\section{Conclusions}

Based on the results of this study, it is concluded that it is possible to evaluate teak pollen quality using these parameters, which will in turn allow pollen management and purification, providing an opportunity for carrying out hybridization trials at an operational scale as part of teak breeding goals in Costa Rica. This was not possible in the past, since previous studies did not emphasize pollen management or the identification of the percentages of viability and initial germination necessary to determine the efficient pollen load for performing controlled crosses.

The results of this research show that $90 \%$ viability and $28 \%$ germination can be achieved in fresh pollen grains, both inside and outside the anther, previously dehydrated in silica gel for 2 and $4 \mathrm{~h}$. Brewbacker and Kwack (BK) medium at $10 \%$ of its salts $+10 \%$ sucrose and at a $\mathrm{pH}$ of 7 must be used as the germination medium.

Author Contributions: Conceptualization, A.H. and O.M.; methodology, A.H., A.R. and L.S.; formal analysis, A.H., O.M.; investigation A.H., A.R., L.S. and M.E.; writing-original draft preparation, H.A.

Funding: This study has been funded by the Division of Research and Extension at the National University of Costa Rica, Institute of Forestry Research and Services of the National University of Costa Rica, Division of Research and Extension at the Technological Institute of Costa Rica, Tree Improvement Cooperative (GENFORES), Ministry of Science, and Technology and Telecommunications of Costa Rica (MICITT) and Novelteak Costa Rica S.A.

Conflicts of Interest: The authors declare no conflict of interest. 


\section{References}

1. Fonseca, W. Manual para productores de teca (Tectona grandis L.f) en Costa Rica [Manual for teak (Tectona grandis L.f) producers en Costa Rica]. SIREFOR (Forest Resources Information System//Sistema de Información de Recursos Forestales). Costa Rica; 2004. Available online: www.sirefor.go.cr/Documentos/Reforestacion/2004 Fonseca_ManualProductoresTeca.pdf (accessed on 20 October 2017).

2. Keogh, R. Capítulo 2: La teca y su importancia económica a nivel mundial [Chapter 2: Teak and its economic relevance worldwide]. In Las Plantaciones de Teca en América Latina: Mitos y Realidades; de Camino, R., Morales, J.P., Eds.; CATIE: Turrialba, Costa Rica, 2013; pp. 8-28.

3. Murillo, O.; Wright, J.; Monteuuis, O.; Montenegro, F. Capítulo 6: Mejoramiento genético de la teca en América Latina [Chapter 6: Genetic improvement of teak in Latin America]. In Las Plantaciones de Teca en América Latina: Mitos y Realidades; De Camino, R., Morales, J.P., Eds.; CATIE: Turrialba, Costa Rica, 2013; pp. 86-111.

4. Keogh, R. Teak (Tectona grandis) provenances of the Caribbean, Central America, Venezuela and Colombia. In Proceedings of the Rio Piedras IUFRO Meeting, Working Group S1.07.09 Rio Piedras, Puerto Rico, USA, 8-12 September 1980; pp. 343-358.

5. Murillo, O.; Badilla, Y.; Rojas, F. Desarrollo del mejoramiento genético forestal en Costa Rica y liderazgo regional con especies tropicales. In Proceedings of the XIV Congreso Nacional Agropecuario, Forestal y Ambiental, (CONAFA), Belén, Costa Rica, 25-27 October 2016.

6. Guzmán, N.; Moya, R.; Murillo, O. Evaluation of bent trees in juvenile teak (Tectona grandis L.f.) plantations in Costa Rica: Effects on tree morphology and wood properties. Forests 2017, 8, 79. [CrossRef]

7. Resende, M.; Murillo, O.; Badilla, Y. Genética Cuantitativa y Selección en el Mejoramiento Forestal; Editorial Tecnológica de Costa Rica: Cartago, Costa Rica, 2018; p. 302.

8. Moya, R.; Marín, J.D.; Murillo, O.; Leandro, L. Wood physical properties, color, decay resistance and stiffness in Tectona grandis clones with evidence of genetic control. Silvae Genet. 2013, 62, 142-152. [CrossRef]

9. Tangmitcharoen, S.; Owens, J. Floral Biology, Pollinization, pistil Receptivity, and Pollen-tube growth of teak (Tectona grandis Linn f). Annu. Bot. 1997, 79, 401-410. [CrossRef]

10. Tangmitcharoen, S.; Owens, J. Pollen viability and pollen-tube growth following controlled pollination and their relation to low fruit production in teak (Tectona grandis Linn f). Annu. Bot. 1997, 80, 401-420. [CrossRef]

11. Palupi, E.; Owens, J. Pollination, fertilization and embryogenesis of teak (Tectona grandis Linn f). Int. J. Plant Sci. 1997, 158, 259-273. [CrossRef]

12. Indira, E.P.; Mohanadas, K. Intrinsic and extrinsic factors affecting pollination and fruit productivity in teak (Tectona grandis Linn.f.). Indian J. Genet. Plant Breed. 2002, 62, 208-2014.

13. Vasudeva, R.; Hanumantha, M.; Gunaga, R.P. Genetic variation for floral traits among teak (Tectona grandis Linn.f.) clones: implications to seed orchard fertility. Curr. Sci. 2004, 87, 358-362.

14. Palupi, E.; Owens, J.; Sadjad, S.; Sudarsono, S.; Solihin, D. The importance of fruit set, fruit abortion, and pollination of teak (Tectona grandis). Can. J. For. Res. 2010, 40, 2204-2214. [CrossRef]

15. Rejón, J.; Suárez, C.; Alché, J.; Castro, A.; Rodríguez, M. Evaluación de diferentes métodos para estimar la calidad del polen en distintos cultivares de olivo [Evaluation of different methods for estimating the quality of pollen in various olive cultivars] (Olea Europaea L). Polen 2010, 20, 61-72.

16. Shivanna, K.R.; Tandon, R. Reproductive Ecology of Flowering Plants: A Manual; Springer: New Delhi, India, 2014; p. 46. [CrossRef]

17. Ganeshan, S.; Rajasekharan, P.E.; Shashikumar, S.; Decruz, W. Cryopreservation of Pollen. In Plant Cryopreservation: A Practical Guide; Reed, B.M., Ed.; Springer: New York, NY, USA, 2008; pp. $443-464$. [CrossRef]

18. Volk, G.M. Collecting pollen for genetic resources conservation. In Collecting Plant Genetic Diversity: Technical Guidelines 2011 Update; Guarino, L., Ramanatha, V.R., Goldberg, E., Eds.; Bioversity International: Rome, Italy, 2011; pp. 1-10.

19. Gónzalez, M.E.; Estévez, A.; Castillo, J.; Salomón, J.; Moré, O.; Hernández, M. La Calidad de la papa: Requerimiento Indispensable del Mejoramiento Genético Tradicional de la papa en Cuba [Potato quality: essential requirement for traditional genetic improvement of potatoes in Cuba]. Rev. Latinoam. Papa 2002, 13, 75-94.

20. Brewbacker, J.L.; Kwack, B.H. The essential role of calcium ion in pollen germination and pollen tube growth. Am. J. Bot. 1963, 50, 859-865. [CrossRef] 
21. Johnson, M.A.; Kost, B. Pollen Tube Development. In Plant Developmental Biology, Methods in Molecular Biology; Hennig, L., Köhler, C., Eds.; Springer: New York, NY, USA, 2010; p. 155. [CrossRef]

22. Abdelnour, A.; Rojas, G.; Alfaro, U. Estudios preliminares para la crioconservación de especies forestales arbóreas. Tecnol. Marcha 2007, 20, 98-103.

23. Di Rienzo, J.A.; Casanoves, F.; Balzarini, M.G.; Gonzalez, L.; Tablada, M.; Robledo, C.W. InfoStat versión. Grupo InfoStat, FCA, Universidad Nacional de Córdoba, Argentina. 2009. Available online: http://www. infostat.com.ar (accessed on 22 July 2019).

24. Statsoft Inc. Statistica (Data Analysis Software System), Version 13.1. 2013. Available online: www.statsoft. com/textbook/ (accessed on 25 July 2019).

25. Taiz, L.; Zeiger, E.; Møller, I.; Murphy, A. Plant Physiology, 6th ed.; Sinauer Associates. Inc.: Sunderland, MA, USA, 2015; p. 705.

26. Yang, W.C.; Shi, D.Q. Plant Developmental Biology—Biotechnological Perspectives: Pollen Germination and Tube Growth; Pua, E.C., Michael, R.D., Eds.; Springer: Heidelberg, Germany, 2010; p. 249. [CrossRef]

(C) 2019 by the authors. Licensee MDPI, Basel, Switzerland. This article is an open access article distributed under the terms and conditions of the Creative Commons Attribution (CC BY) license (http://creativecommons.org/licenses/by/4.0/). 